\title{
History of rice production in the Mekong Delta
}

\author{
J.F. Le Coq ${ }^{1}$ M. Dufumier ${ }^{\text {2 }}$ and G. Trébuil ${ }^{1}$
}

\begin{abstract}
During the years following the application of its economic liberalisation policy, Vietnam experienced a dramatic growth in rice production permitting to reach food self-sufficiency at the national level and also to become a major rice exporting country. This article emphasises the importance of an historical approach to agricultural development to fully understand the rapid and tremendous effects of this relatively recent agricultural policy.
\end{abstract}

A comprehensive study of the long-term evolution of rice production systems in the Mekong Delta, the largest rice bowl of Vietnam, was conducted to differentiate between past and more recent reasons of the rapid growth in rice production.

This study which is based on a historical analysis of key agrarian changes that occurred during the last century proposes a review of the available literature, especially old reports and monographs, and also relies on original data collected during many semi-structured farmers' interviews carried out in a small region of the central plain of the Mekong Delta, the Omon district. Particularly, the interviews addressed the characterization of major technical, economic, social and institutional changes in the farm environment that occurred during the last five decades.

The article demonstrates how the reforms imposed during the colonial times could partly explain the recent rapid growth of paddy production. It shows how the land reclamation of the Mekong Delta, that begun under the Vietnamese Empire in the early XVII's century, accelerated thanks to the improvement of an extensive network of transportation and drainage canals built under the French colonial administration. The small paddy growers were then able to expand rice cultivation across almost all the Mekong Delta by adapting their farming systems to each type of rice ecosystem. As soon as the thirties, Cochinchina became one of the major rice exporting region. But the impressive polarisation of the rural society created by the French colonial administration was limiting productivity growth and generated serious social conflicts, leading to a drastic decrease of rice production.

The growth of rice production since the launching of the market liberalisation policy in the late eighties was mainly the result of an acceleration of the intensification process of the local rice production system. This transformation of rice production practices begun in the late sixties with the first introductions of potentially high yielding "green revolution" semi-dwarf rice varieties and the implementation of the land to the tiller reform. Thanks to major improvements in water control allowing multiple cropping, this crop intensification process consisted mainly in an extension of the irrigated rice ecosystem, while the other types of less productive rice ecosystems receded. These profound changes were achieved by smallholders, owning their means of production and willing to invest in fixed capital, working capital and labour to maximise land productivity and to improve their incomes. By allowing farmers to recover a capacity for accumulating means of production, the more recent economic reforms permitted to speed up this impressive rice intensification process.

\footnotetext{
${ }^{1}$ Cirad-ECOPOL programme, 45 bis, Avenue de la Belle Gabrielle, 94736 Nogent-sur-Marne, France. Tel: 331439473 15, Fax: 331439473 11, E-mail : lecoq.jf@cirad.fr. Corresponding author.

${ }^{2}$ INA PG, Chaire d'agriculture comparée et de développement agricole, 16, rue Claude Bernard, 75005 Paris. Tel: 331440817 08, Fax 331440817 27, E mail: dufumier@inapg.inra.fr

${ }^{3}$ Cirad-Food Crops programme and International Rice Research Institute, Los Baños, Laguna, The Philippines. Department of Annual Crops-Cirad, TA 73/09, avenue Agropolis 34398 Montpellier Cedex 5, France. Tel: 334676171 12, Fax: 334676155 12, E-mail: guy.trebuil@cirad.fr
} 


\section{Introduction}

During the years following the implementation of its economic liberalisation policy, Vietnam experienced a dramatic growth in rice production that allowed the country to reach food self-sufficiency at the national level and even to become an important rice exporter. Vietnam could then be considered as a successful example of a quite liberalisation policy. Those good results are often described as the effects of the reforms themselves (L.P. Pingali and Vo Tong Xuan, 1992; G. Schulders, 1997). Based on a historical approach aiming at a full understanding of the tremendous effects of this relatively recent agricultural policy, we tried to separate the role of the liberalisation policy from other agricultural pre-existing conditions to explain the development process of Vietnam.

This study focuses on the Mekong Delta, the main rice bowl of the country (figure 1) producing $51 \%$ of the national production in 1995. It displays the highest per capita paddy production with around 0.8 ton of paddy per inhabitants and per year and provides around 80 $\%$ of the total amount of rice exported by Vietnam in 1995 (Lebailly P. et al., 2000). By achieving the highest growth rate of paddy production between 1985 and 1995, the Mekong Delta contributed very significantly to the impressive results in term of rice production and exports growth at the national level following the start of the implementation of the liberalisation policy.

\section{Materials and method}

To understand the respective roles played by the economic liberalisation policy and other changes, we studied the long-term evolution of the rice production system in the Mekong Delta. A comprehensive explanation of the rapid growth of rice production in the Mekong Delta is proposed, based on an historical analysis of all key agrarian changes that occurred during the last century.

This study is based on a review of the available literature, especially old reports and monographs, and on original data collected during many semi-structured farmers' interviews carried out in a small region of the central plain of the Mekong Delta, the Omon district (figure 2). Particularly, the interviews addressed the identification and the characterization of each major technical, economic, social and institutional changes in the farm environment that occurred during the last five decades. The results explain the effects of the hectic evolution of the socio-economic environment on farms (figure 3) and their consequences in term of rice production (figure 4.a and figure 4.b).

\section{From the III $^{\text {th }}$ century to the mid-XIX ${ }^{\text {th }}$ century: Land reclamation and expansion of the rice growing area}

\section{From the III $^{\text {th }}$ century to the XVII ${ }^{\text {th }}$ century: Land reclamation before the Vietnamese colonisation}

Few data are existing to describe thoroughly the agricultural colonisation of the Mekong Delta by the Vietnamese. Archaeological findings show that the Mekong Delta was partly occupied by Khmer people of the Chen La kingdom between the III $^{\text {th }}$ and the VI $^{\text {th }}$ century (Malleret L., 1962; Kenneth R.H., 1977, Nguyen Van Long, 1984, Nguyen Xuan Hien, 1984 cited by Nguyen Huu Chiem, 1994). If this population did practice rice cultivation, probably deep-water rice or floating rice systems, it's main economic activity was commerce. After the decline of this kingdom and of the Oc Eo harbour, the Mekong Delta was still occupied 
by Khmer people belonging to the Angkor Empire (Groslier B.P., 1961; Coedes G., 1962). But the main land reclamation process which conducted to the present situation begun with the Vietnamese colonisation of the Mekong Delta during the XVIII's century.

\section{From the XVIII ${ }^{\text {th }}$ century to the late XIX ${ }^{\text {th }}$ century: Land reclamation under the Vietnamese empire}

In the XVIII ${ }^{\text {th }}$ century, Vietnamese migrants coming from the northern and central regions reached the Mekong Delta. This population of migrants, mainly made of poor peoples, reclaimed the land lying next to the natural communication ways, the rivers. They settled down on the natural levees of the Mekong and Bassac rivers as well as other rivers in the upper part of the alluvial plain. They cultivated the areas next to their houses, mostly rainfed shallow submergence prone and rainfed medium deep waterlogged ecosystems. They practised a kind of traditional transplanted local rice production system (figure 5) permitting the reproduction of their labour force. In the gardens surrounding their houses, farmers produced a large range of non-rice crops, such as vegetables, tubers and fruits (Aubaret G., 1863). In association with crop cultivation, were rearing water buffaloes and cattle as draft animals, as well as swine and poultry. Concurrently, on the uncultivated areas, they were fishing and hunting to complement their diet with more proteins (figure 5).

During this land reclamation, the Vietnamese Empire administration expanded its control in this area. It promoted an expansion of the cultivated areas to secure control over new territories. The Vietnamese Empire administration let farmers free to settle where they wanted (Aubaret G., 1863). It did not provide farmers with any direct help to settle and to reclaim land. It only granted land use rights cultivating it and paying the land tax (Schreiner A., 1900). Under such conditions, according to their initial endowment in fixed and working capital, migrants managed to become "owners" and to cultivate different amounts of lands (figure 6). Migrants possessing draft animals could rent them or give loans to poor farmers and get extra labour force from those more disadvantaged families to expand larger farms. On the contrary, small farmers cultivated just what they could handle with their own family labour force or by relying on mutual aid, especially at rice harvest. Following the creation of the villages, the new migrants had to stay out of the village ("non-registered" people- "Dan Lau") and could not have their own land to farm in the villages. They became hired labour on farms belonging to the village dignitaries.

During the second half of the XIX ${ }^{\text {th }}$ century, prior to the French colonisation of the Mekong Delta, the process of land reclamation by the Vietnamese population under the Vietnamese Empire did not reach its maximum expansion. Only a small part of the Mekong Delta was then cultivated. In the Omon district, in 1836 , only $4 \%$ of the area was cultivated ${ }^{4}$, consisting of the natural levees and a part of the upper floodplain. Rice fields represented $78 \%$ of this cultivated area. According to Henry Y. (1932), in 1868, the rice growing area corresponded to only $4 \%$ of the Cochinchina region. As shown in figure 6 , the farming conditions among village families were quite contrasted.

\footnotetext{
${ }^{4}$ This estimation is based on our analysis of the land use "cadastral" data of 1836 cited by Nguyen Dinh Dau (1995) for the « Dinh Thoi » district.
} 
Figure 6. Farmers categories in the Omon district during the Vietnamese imperial and the French colonial regimes.

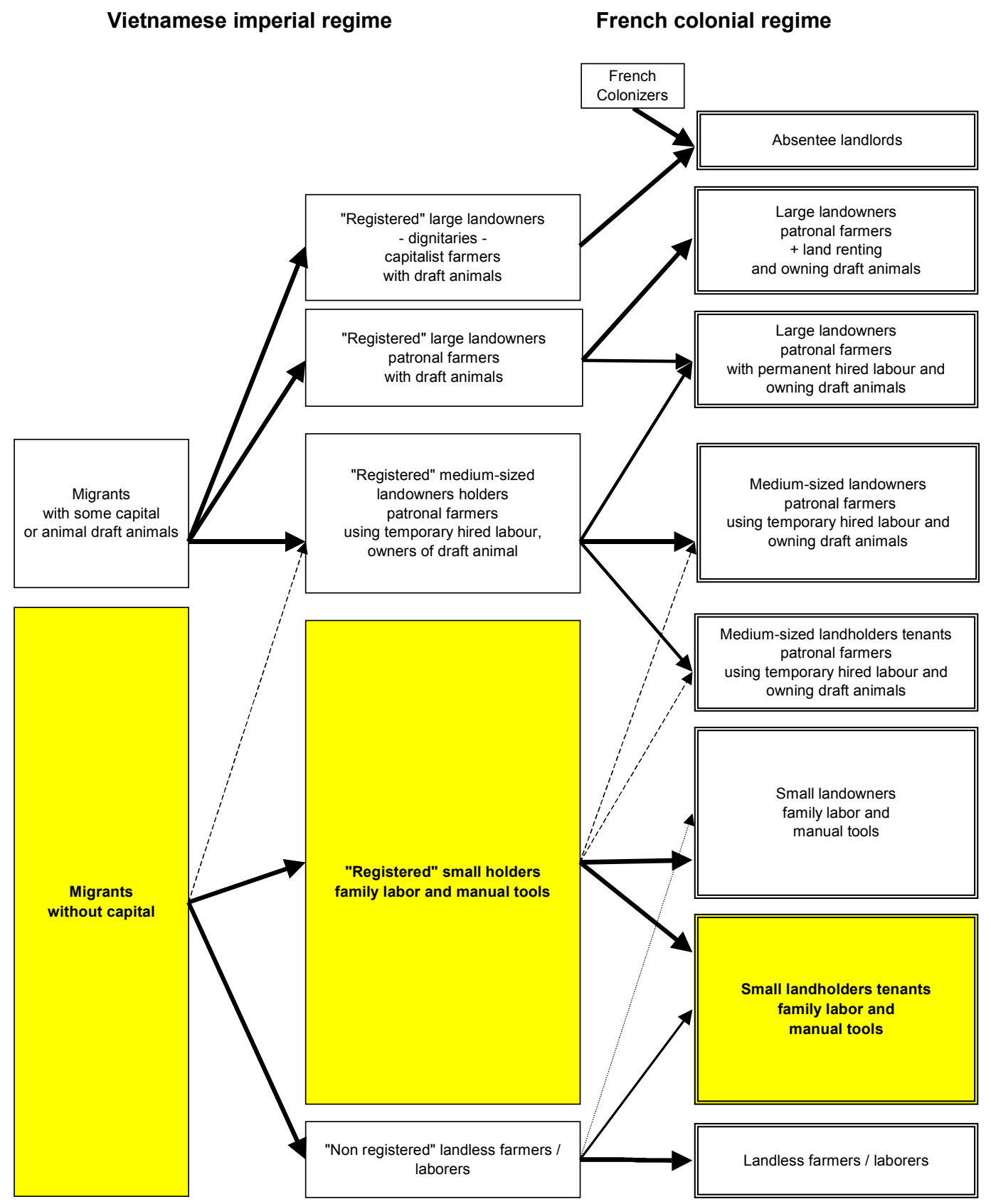

NB: $\quad$ The main categories are in grey.

From the late $X I X^{\text {th }}$ century to mid-XXth century: rapid expansion of the rice growing area and strong social polarisation under the French colonial regime

Although the Mekong Delta was only partly cultivated, it was colonised by the French at the end of the XIX ${ }^{\text {th }}$ century. In order to take advantage of this new territory, the French colonial administration wanted to develop rice production and extend the rice growing area. It invested in the development of infrastructures, especially the digging of primary canals allowing drainage and transportation through the whole Mekong Delta (Robequain C., 
1939). From the 1880 to the 1930 's, almost $1.800 \mathrm{kms}$ of canals were dug (IGTP, 1930). Thanks to hydraulic network, the settlement of the population and the land reclamation of most of the fallow areas became possible.

Concurrently to those investments, the French colonial administration modified deeply the farm socio-economic environment. In order to encourage land reclamation and to increase its fiscal revenues, it maintained a low rate of the land tax of about $2 \%$ of the gross production ${ }^{2}$. But the administration expanded the target of personal taxes to the whole population, "registered" as well as "non registered" people). Moreover, it deeply modified the land tenure system. Although the Vietnamese administration didn't interfered with land appropriation by farmers and recognised only land use rights, the French administration issued private property rights. In order to speed up the land reclamation process, it relied on French colonists and Vietnamese dignitaries and granted them large concessions of uncultivated land, especially in the lower floodplain.

Under those conditions, the intervention of the French colonial administration led to a strong differentiation between private property and the development of the non-owner kinds of tenure (figure 6). This process strongly increased the polarisation of the agrarian society. Around $1930,62 \%$ of the land owners possessed only $9 \%$ of the rice fields and $4 \%$ of them owned $48 \%$ of the paddy fields (Henry Y., 1932). Based on data provided by Y.Henry and M. De Visme (1928) and Y. Henry (1932) and by taking into account the whole population, we estimate that $72 \%$ of rural households possessed no land and that $2 \%$ of them, owning more than 50 hectares, possessed around $48 \%$ of the land. Consequently, the agrarian society was mainly composed by a small class of large landowner draining rice production surpluses for exports by charging heavy land rental fees and high interest rate of their loans, and a large class of smallholders, mainly tenants, who could not accumulate any investment capacity from their rice production and were maintained in very poor living conditions.

Nevertheless, the expansion of rice cultivation that began under the Vietnamese administration increased dramatically under the French colonial regime. Between 1880 and 1930, the rice growing area of Cochinchina jumped four times from 520,000 to 2,200,000 hectares (Henry Y., 1932). From primary canals, landlords developed a network of secondary canals, especially in the lower floodplain, to secure a better drainage. In the upper floodplain, sometimes farmers organised themselves to control the submersion and the drainage of small plains by building small dams. By this ways, farmers brought under cultivation the land of all the various ecosystems by using different varieties and by adapting their cultivation practices (figure 7).

In the 1930s with the exception of the plains of reeds, almost all the present primary canals in the Mekong Delta were dug and many secondary canals too. Most of the land was cultivated. The production of Cochinchina is estimated at around 2.5 millions tons of paddy and the production per capita reached around $0.5-0.6$ tons of paddy (estimation based on Y. Henry \& M. De Visme,1928 and Y. Henry, 1932). In those days Cochinchina was one of the three major rice exporting regions, with around 1 million tons of white rice shipped every year (Robequain C., 1939). But the strong social polarisation limited the efficiency of the rice production system (low yield, low labour productivity). Most of the farmers were tenants and saw their production being taxed by landlords through rental fees and interest rates of loans and had no tenure security. Their standard of living was very low as they had

\footnotetext{
${ }^{5}$ Estimation of the authors based on data provided by P. Melin (1939).

${ }^{6}$ In the thirties, according to P. Melin (1939), the land rents was equivalent to 30 to $40 \%$ of the production.

${ }^{7}$ The interest rates of loans were set between 10 to $20 \%$ per month (Henry Y., 1932; Gourou P., 1942).
} 
no investment capacity and could not use draft animals or carry out the land improvement works which were necessary to improve the efficiency of their production systems. Thus, although farmers tried to get better yields by increasing labour intensity, rice yields remained under 2.5 tons of paddy ha $^{-1}$ year $^{-1}$, and the labour productivity was still limited to some 20 $\mathrm{kg}$ of paddy man-day ${ }^{-1}$.

\section{From mid-XIX ${ }^{\text {th }}$ century to 1975: re-organisation of the social structure and beginning of rice intensification}

\section{5-1954: Agricultural dereliction and re-organisation of the social structure during the Indochina war}

At the end of the thirties, the social polarisation created by the colonial regime became explosive. Some farmers' revolts broke out to fight for lower land rents and lower taxes (Brocheux P., 1995). After 1940 and the downfall of the French colonial power following the Japanese invasion, the rebellion movement increased with the creation of the Vietminh movement and the Indochina war began. In this war times, the countryside became unsecured for the population which began to leave their land and villages. Under the pressure of the Vietminh, landlords could neither claim their land rents nor recover their loans from tenants and began to fly away. As a consequence, some tenants were free from land rents and achieved better living conditions. But during the war context, means of productions were destroyed (water buffaloes and cattle) and the hydraulic network and other key infrastructures were not maintained and deteriorated. Consequently, during this period, the production fell down as a result of a decrease in the cultivated area, associated with a fall in land productivity. In spite of a re-reclamation of land at the beginning of the fifties, the rice production was still low (figure $4 \mathrm{a}$ and $4 \mathrm{~b}$ ) and the exports from Cochinchina to the world market were limited to less than 200.000 tons of white rice.

\section{5-1967 : First land reform under the Ngo Dinh Diem government}

In 1954, the Indochina war ended and the country was split into two parts: southern Vietnam became the Republic of Vietnam (RSV) and Northern Vietnam, the Democratic Republic of Vietnam (DRV). In the south, after a short period of lull, the conflict started again. To gain the support of the rural population, both the government of RSV, directed by Ngo Dinh Diem, and the National Liberation Front, associated with the DRV, carried on land reforms in the areas under their respective control (Callison C.S. 1983; Lam Thanh Liem, 1987). In 1955 , by the ordinance $n^{\circ} 2$, the government of the RSV limited the level of land rents and recognised the land occupation by farmers. In 1956, by the ordinance $\mathrm{n}^{\circ} 57$, it reformed the land tenure system. As a maximum limit of 100 ha for land ownership was put in place, the government seized land from landlords and sold it to farmers. In this way, the larger landowners were expropriated and some tenant farmers became landowners (figure 8).

Concurrently, in order to develop agricultural production, the government of the RSV introduced mineral fertilisers and motorised equipment as 4-wheel tractors. As a result, the beginning of rice intensification of the former production systems started (figure 9).

Nevertheless, if this policy allowed the government to reduce the level of inequality in the rural society, the war context still limited the intensification of rice production and agricultural development.

In 1963, Ngo Dinh Diem was killed and southern Vietnam went through five years of political instability, as the Vietnam War engulfed the area with the increasing involvement of the United States of America. 
Figure 8. Farmers categories in Omon district during the Republic of South Vietnam (19551975).

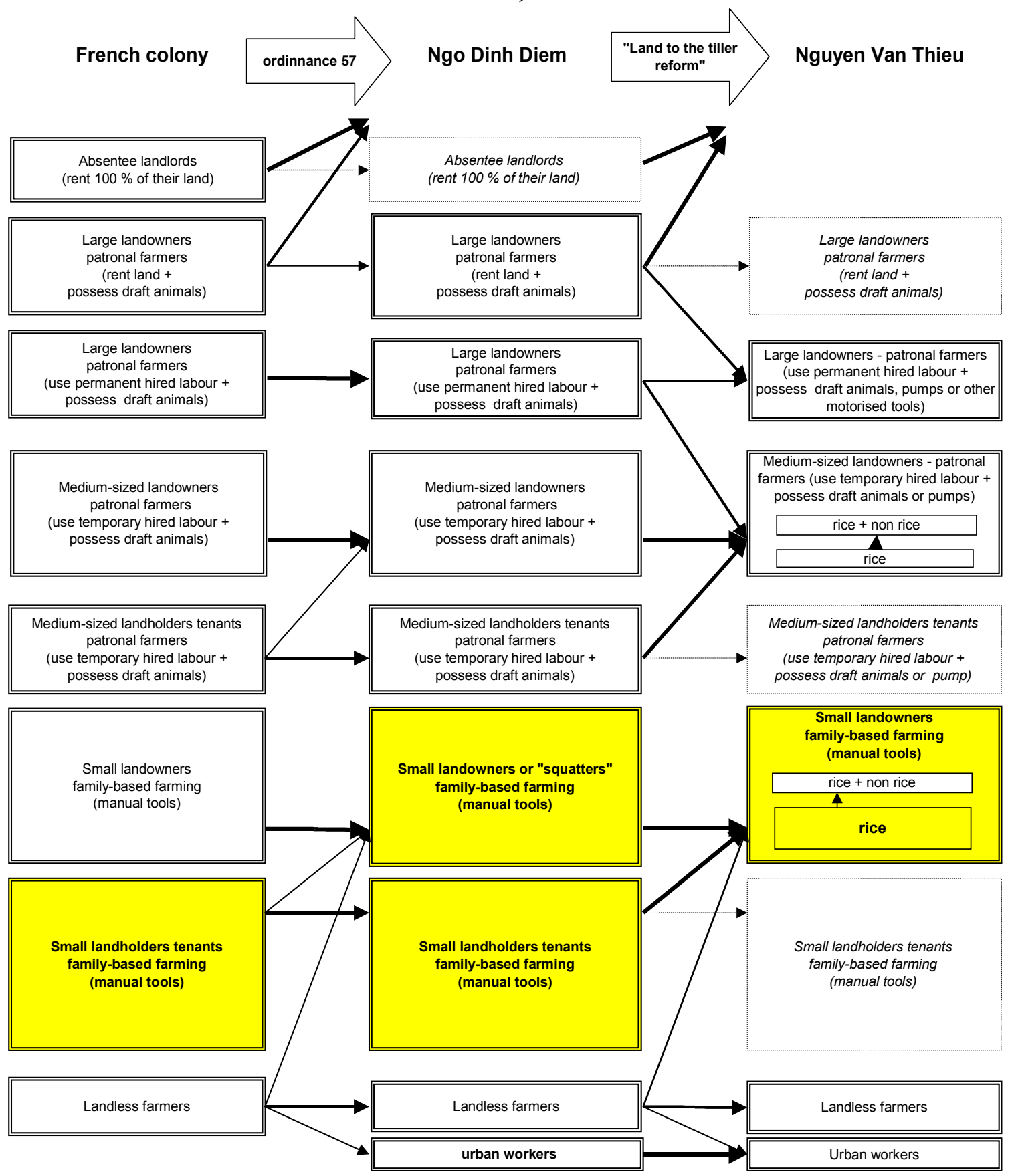

NB: $\quad$ in grey: main categories;

In dotted line frame and italic characters: disappearing categories. 


\section{8-1975: The "Land to the tiller reform" and the introduction of the "green revolution"}

In 1967, a new government is formed under the authority of General Nguyen Van Thieu. Financially and military supported by the United States of America, this government launched a new land reform known as the "land to the tiller" (Callison C.S. 1983). According to this law, all the land which is not directly cultivated is given to farmers. So the social structure inherited from the colonial period is totally reformed. Almost all the farmers that were tenants became landowners (figure 8). They had no land rent to pay and could generate an investment capacity.

Concurrently, the first High Yield Rice Varieties (HYV) were released such as IR 5 and IR 8 (Denning G.L. and Vo Tong Xuan, 1995). To help farmers to adopt these new rice varieties and take advantage of them, the government, with the help of the USA developed the import of chemical inputs (fertilisers and pesticides) as well as motorised equipment (tube pumps, hand-tractors and small motorised threshers). It also developed a rural credit system (Vo Tong Xuan, 1975).

Under those conditions, on the natural levees and the upper floodplain where it was possible to grow them without important improvement in the hydraulic network improvement at the regional level and by using the natural tidal movements of inland water, farmers began to adopt those new semi-dwarf HYV (figure 10). As for that, they completed the local irrigation and drainage network (tertiary canals) and improved the land conditions by building dikes. This way, they quickly took advantage of this new HYV to increase dramatically their land productivity. Although with the traditional rice production (TR) system the land productivity did not exceed 3.5 tons of paddy $\mathrm{ha}^{-1} \mathrm{an}^{-1}$, with the new HYVbased irrigated rice production system farmers could harvest around 6 tons of paddy ha $\mathrm{an}^{-1}$ ( $1 \mathrm{HYV} / 1$ TR system) and 8 tons of paddy $\mathrm{ha}^{-1} \mathrm{an}^{-1}$ with $2 \mathrm{HYV}$ crop cycles per year. With too few motorised equipment available, those high-yielding systems were more labour intensive than the traditional rice production system. Their expansion was limited by the scarcity of rural labour resulting from the war and the associated rural exodus.

In the lower floodplain, the adoption of the intensive and HYV-based irrigated rice system was still impossible because :

- the hydraulic network planned for drainage only could not be used for irrigation. Most of the secondary canal were empty during the dry season and there was no tertiary canals;

- the tube pumps, necessary to irrigate those areas where no irrigation could be provided by the natural tidal movement of inland water were too scarce and

- insecurity was still high in those more remote and loosely populated areas.

Finally, at the Mekong Delta level, thanks to the start of the "green revolution" mainly in the central plain, the rice production increased rapidly during the beginning of the seventies (Fukui H., 1974). According to the data of the Ministry of agriculture, Directorate of Agricultural Economics (1974) reported by Vo Tong Xuan (1975), from almost zero in 1968, HYV were grown on 890.000 ha in 1973 (31\% of the total rice cultivated area) and provided around 3 millions tons of paddy ( $45 \%$ of the total rice production). But, although the expansion of the HYV-based irrigated rice production system is rapid, it is still limited at that time by the war context, the limited amount of rural labour and a relatively poor irrigation network. 


\section{1976-1985 : Expansion of "green revolution" under the administrated economy of the Socialist Republic of Vietnam}

In 1975, the Republic of South Vietnam surrendered and in 1976 southern and northern Vietnam were reunified to give birth to the Socialist Republic of Vietnam (SRV). After almost 30 years of terrible conflicts, Vietnam suffered from an acute deficit of rice production, estimated at 2 to 3 millions tons of Paddy (Feray, 1990).

In those conditions, the first Five-year plan $(1976$ - 1981) decided to extend to southern Vietnam and the Mekong Delta a state-planned economy and a socialist type of agricultural organisation. But, in spite of the willingness of the central authorities, the collectivisation of agriculture in the Mekong Delta is not effective possible because farmers who had obtained lands property rights after 30 years of conflicts offered a strong resistance to their integration in "collective structures". In fact, farmers continued working on their lands, with their own tools and the local agriculture remained mainly based on family smallholders. With peace, a number of farmers who had flied away to towns to avoid the fighting, returned to countryside. This resulted in an increase of the rural labour force and a decrease in average size farm (figure 11). In those conditions, the labour scarcity that limited the expansion of the HYV-based irrigated rice production system was not existing anymore. So many farmers continued to switch to this more intensive irrigated rice production system on natural levees and the upper floodplain. But, with the prohibition of private trade and the state monopoly on external trade, they met with problems to get agricultural inputs and yield level decreased. As an example, although the HYV crop in Phong Dinh Province in 1973 was 3.8 tons of paddy ha $^{-1}$ (Ministry of Agriculture, directorate of agricultural economics, cited by Vo Tong Xuan, 1975), in 1980, in the Can Tho province, the yield of HYV crop of rainy season ("lua He Thu") and those of dry season ("lua Dong Xuan") were 2.4 and 3.0 tons of paddy ha ${ }^{-1}$ respectively, according to the General Statistical Office.

In spite of the expansion of the intensive irrigated rice system in the Mekong Delta, the food production deficit at the national level was still important and reached a record level in 1978 when the Brown Planthopper damages affected a large part of the susceptible HYV crop in the Mekong Delta (Denning G.L. et Vo TongXuan, 1995). Then, the government decided to change its policy.

In the second Five-year state plan (1981-1985), the government still wanted to control commercial activities. But it decided that the land should be distributed among farmers of the "collective structures" according to the number of workers and non workers in the family. So, even in the "collective structures", the government recognised that each farmer could cultivate the land by himself, and that the actual production unit was still the farm household. Heavy equipment became the property of "production groups" and were managed by the chief of each group. The "production groups" were also in charge of supplying inputs and marketing the production. Therefore, they represented the last level of the state commercial network. They announced to farmers the state directives and controlled their applications.

Although the "collective structures" wished by the state at the end of the seventies did not exist, farmers joined those "production groups" at the beginning of the eighties because:

- the pressure on farmers to integrate those "groups" became stronger as the administration improved its local organisation, 
- by doing so, farmers found a way to get access to agricultural inputs that they could not find easily, or only at very high price on the black market,

- for some farmers, like landless and very small ones, entering a "group" was a way to get more land to cultivate,

- in those new types of "groups", not like in the former ones where they were just salaried employees, their family farmer status was not denied, e.g. they could still manage their farms and get their income from their own production.

In those "groups", all producers were yet smallholders (figure 11). All were mostly interested in increasing the rice productivity per land unit as they were now free to sell on the market the volume of their production surpassing the target yield stated in their "contract" with the "collective unit".

Nevertheless, the rice intensification was still limited. On the levee and the upper flood plains, the hydraulic network was completed by the "production groups" and allowed to expand the double cropping system of HYV on the lowest lands. At the field level, farmers carried out manually the land improvements that were necessary to improve water control and be able to adopt the irrigated rice production systems. By using the tidal movements of the water level and sometimes pumps to irrigate and to drain their fields, they managed to introduce double cropping systems of HYV on almost all the land of the levees and the upper floodplains by the end of the eighties (figure 12). On the lower part of the floodplain, although the water drainage network was re-dug under the authority of the "production groups" to make it more efficient, farmers could not grow irrigated HYV-based cropping systems because :

- the irrigation network was still incompleted,

- the local land improvement works were not yet realised, because of the lack of tractors as those areas were too large to carry out land improvements manually and,

- they lack pumps to irrigate their fields.

While farmers aimed at increasing their production per unit of land, the predominant marketing system did not favour this goal for several reasons. First, the state distribution system of inputs did not work well, and often farmers got only a small amount of fertilisers and/or pesticides, and frequently not when they needed it. Moreover, if it was possible to get some inputs on the private market, they often could not buy them because it was too expensive. Secondly, through the contract system, farmers had to sell a fixed amount of their production at very low prices. But this amount was often defined at such high level that they had to sell all their paddy to the state at low price. By doing so, they only got enough income from their production to reproduce their labour force or at best to get a very low revenue that they were not encouraged to invest in agricultural means of productions as no private property rights were recognised.

With the completion of the expansion of the irrigated rice agro-ecosystem, the Mekong Delta production increased during this period to reach 6.8 millions tons of paddy in 1985, that is to say a per capita rice production equivalent to some 0.5 tons of paddy. But due to the stagnation of the rice production in northern Vietnam, even if food self-sufficiency at the national level seemed to be reached since the middle of the eighties, the SRV government decided to implement a bold liberalisation policy. 
Figure 11. Evolution of farmer's categories in Omon district during the first decade of the Socialist Republic of Vietnam (1975-1985).

Around 1975

Around 1980

Around 1985

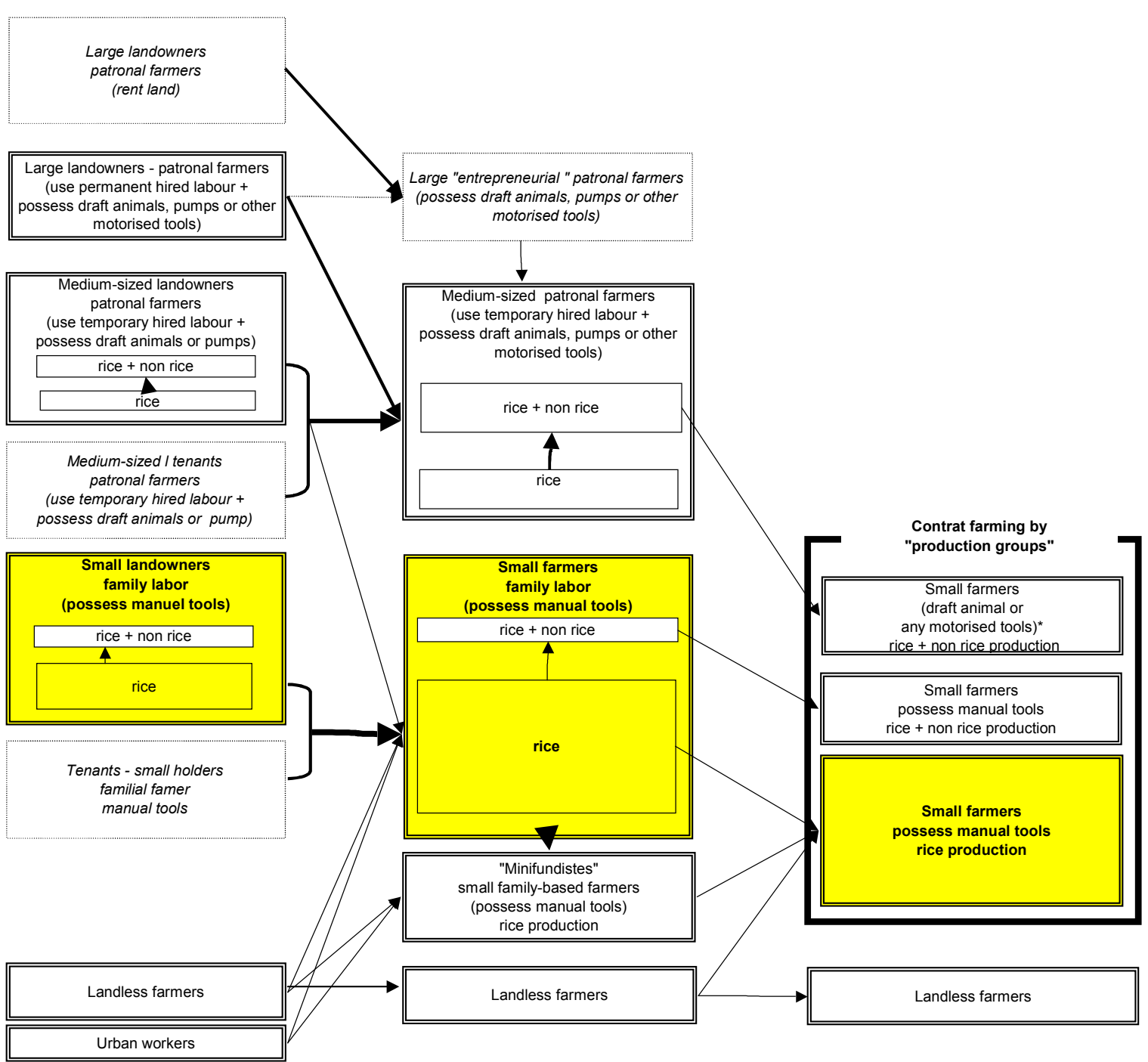

NB: in grey: main categories,

*Equipment and tools indicated are the properties of the "production groups". 


\section{1986 - 2000 : Rapid rice intensification following the agricultural liberalisation policy}

In the late eighties, following the $\mathrm{VI}^{\text {th }}$ plenum of the CPV (Communist Party of Vietnam), the SRV government decided to implement a wide-ranging economic liberalisation policy (Lam Thanh Liem, 1991; L.P. Pingali and Vo Tong Xuan, 1992; Dao The Tuan, 1997). Among other bold decisions, it recognised free market exchanges and the key role of the family based agricultural economy.

Farmers could now sell their product on deregulated markets at higher prices and access more easily a capacity for the accumulation of means of production. On the other hand, following with the liberalisation of the domestic market for inputs, the private commercial network expanded rapidly. With the reorientation of paddy production for exports, the imports of mineral fertilisers and pesticides also increased dramatically. Between 1985 and 1995, the amount of imported mineral fertilisers has grown from some 350,000 tons to $1,264,000$ tons that is to say $260 \%$ on this period. Under this new kind of farmer environment, farmer's access to those inputs became easier and they immediately used their newly recovered investment capacity to intensify their rice-based production systems and to increase paddy yields. Thus the average yield in the Mekong delta increased by $32 \%$ from 3.05 tons to 4.02 tons ha ${ }^{-1}$ between 1985 and 1995 .

Subsequently, the government recognised the "ownership" of the means of agricultural production and gave the land back to farmers. In the Mekong Delta where the "production groups" last only very few years, farmers recovered the cultivated areas they used to farm prior to their integration in those "production groups". Heavy farm equipment that was handled by these "groups" were given back to their former owners or sold. Thus the dissolution of these "production groups" led to a restoration of a significant level of differentiation among farmers regarding land tenure and farm equipment (figure 13). Under these new market conditions, large farms were rapidly able to improve their accumulation capacity to buy motorised tools, such as pumps, hand tractors and axial flow threshers. Then the relative scarcity of those motorised equipment disappeared. By using them as a contractors, they allowed poorer farmers who did not possess any of those equipment to use them and also increase labour productivity on their smaller farms. This way, the vast majority of farmers could better manage soil preparation and water management which, in association with an increasing use of fertilisers and pesticides, contributed to an increased land productivity of their rice systems. Consequently, from an average yield of 7 tons of paddy year ${ }^{-1} \mathrm{ha}^{-1}$ level with $2 \mathrm{HYV}$ crops per year, they were now harvesting around 10 tons of paddy year ${ }^{-1} \mathrm{ha}^{-1}$ from their irrigated paddy fields

Beyond increasing the land productivity level of the double rice cropping systems they already practised before, farmers also used those equipment to increase the cropping index of their land use system (figure 14). On the levee and the upper flood plain, they switched from a 2 HYV crops per year to a $3 \mathrm{HYV}$ crops per year system that allowed to reach a land productivity level of 14-15 tons of paddy ha $^{-1}$ year $^{-1}$.

But if the state recognised the private market role in the economy, it still organised the development of irrigation systems. By investing in the re-digging of canals and organising the improvement of the village-level irrigation networks, the irrigation of the paddyfields lying on the lower flood plain became possible. By using tractors equipped with front blade, farmers levelled the fields and built dikes around them to control water. They switched from deep water rice based system to irrigated HYV-rice based cropping systems and their land productivity jumped from 3-4 to 9-10 tons of paddy ha $^{-1}$ year $^{-1}$ with 2 crops per year. 
Figure 13. Evolution of farmers categories during the Socialist Republic of Vietnam after the implementation of the liberalisation policy (1985-1995).

Around 1985

Around 1990

Around 1995

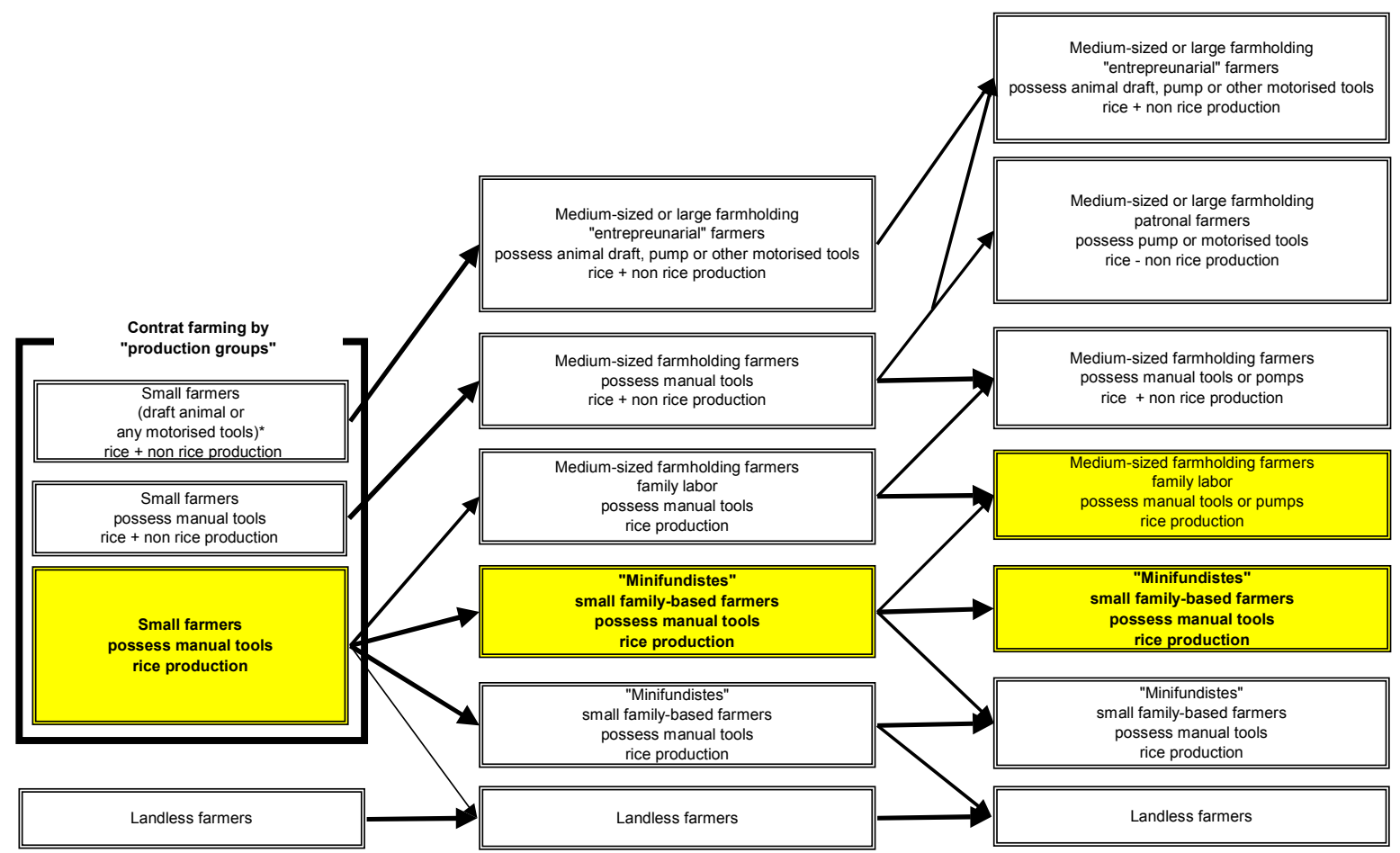

NB: $\quad$ in grey: main categories 


\section{Conclusion}

The detailed historical analysis of the long term evolution of rice production in the heart of the Mekong Delta allows to better understand and to interpret the rapid and dramatic agricultural growth that followed the implementation of the liberalisation policy. These bold changes can be considered as the result of an acceleration by familial smallholders of the process of intensification of the rice production system through increases in fixed capital, working capital and labour aiming at increasing land and labour productivity. This study shows that small family farmers, when they work for them, tend to use their family labour force to increase their agricultural revenue of their labour force through intensification of their production systems while other non agricultural opportunities are scarce or/and less remunerative. With this objective, the small family farmers of the Mekong Delta, as soon as they had been free to choose their activities and recover a suitable environment in terms of means of production availability, had made an efficient use of the production factors, especially labour force, in a way that met the interest of whole nation, here, through rice production increase.

The historical approach shows that, in the case of the Mekong Delta, the success of the economic liberalisation is partly due to the existing local situation prior to the implementation of this policy. Particularly, two key points can be stressed. First, the relatively good agricultural infrastructures, especially the water control, inherited from the previous political regimes, that ensured easy transportation of goods through the countryside. It also permitted to adopt relatively rapidly the irrigated rice production system after just

some local land improvement works carried out by farmers themselves. Secondly, the social structure created over the previous decades was such that all the farmers were interested in increasing land productivity and were willing to invest fixed capital, working capital and labour to reach this goal. Thus, this case study demonstrates usefulness of an historical approach to understand the effects of a relatively recent agricultural policy. It also warns us against rapid extrapolations of a locally successful agricultural policy from a given country or a sub-national region to another one.

If the reason of the rapid and dramatic increase of rice production in the Mekong Delta through cropping system intensification could be grasped by an historical approach, the present situation of the agriculture is nowadays different. The level of rice intensification is now high and the increase land productivity in rice cultivation is a new challenge so as further intensification in chemical inputs and water use leads to environmental issues in terms of water resources (quality and quantity). Moreover the recent development of the agriculture was also marked by a diversification of the production (figure 3 ) and a wider differentiation among farmers (figure 13) that raised new socioeconomic issues. 


\section{Cited references}

Aubaret G., 1863 - Histoire et description de la Basse Cochinchine (pays de Gia Dinh) Imprimerie Impériale, Paris. Republié en 1969 par Gregg International Publishers Limited, West mead, Farnborough, Hants, Royaume Uni, 359 p.

Brocheux P., 1995 - The Mekong Delta : Ecology, Economy and Revolution, 1860-1960 Univesrity of Wisconsin-Madisin, Center for Southeast Asian Studies, Monograph $\mathrm{N}^{\circ} 12$, Etats-Unis, 269 p.

CALLISON C.S., 1983 - Land-to-the-tiller in the Mekong delta, economic, social and political effects of the land reform in four villages of South Vietnam - monograph series n²3, Center for South and Southeast Asain Studies, University of California, Berkeley, University Press of America, 1983, $391 \mathrm{p}$.

Coedes G., 1962 - Les peuples de la péninsule indochinoise, histoire et civilisation - Paris, Dunod, 110 p.

Denning G.L. \& Vo Tong Xuan, 1995 - Vietnam and IRRI: Partnership in rice research IRRI, MAFI, Proceedings of a conference held in Ha Noi, 4-7 may 1994, 353 p.

FERAY P.R., 1990 - Le Viêt-nam - deuxième édition, collection Que Sais-je ?, PUF, Paris, 127 p.

FUKUI H., 1974 - An agro-environmental study of Vietnamese part of the Mekong Delta - in SouthEast Asian Studies, Vol 12, N², septembre, Kyoto, Japon, p.157-176.

Gourou P., 1942 - L'utilisation des sols en Indochine -, CEPE, publication n²14, Paul Hartmann éditeur, Paris, 465 p.

GrosLier B.P., 1961 - Indochine, Carrefour des arts - Albin Michel, Paris, 281 p.

HenRY Y. \& De Visme M., 1928 - Documents de démographie et riziculture en Indochine BEI, Ha Noi, 66 p.

HENRY Y, 1932 - Economie agricole de l'Indochine - Gouvernement Général de l'Indochine, Ha Noi, 696 p.

IGTP, 1930 - Dragages en Cochinchine - Gouvernement général de 1'Indochine, Saigon, 80 p.

KenNeTH, R. H., 1977 - The age of Fu Nan: The emergence of the SEA political economy in the early Christian Era - Ball State University, Muncie, Indiana, USA (edited by Nicolas Tarling, 1992) The cambridge history of South East Asia, Vol 1, pp. 185-192.

LAM Thanh Liem, 1987 - Collectivisation des terres: l'exemple du delta du Mékong - SEDES, Paris, $101 \mathrm{p}$.

LAM THANH LIEM, 1991 - L'économie rurale vietnamienne : Bilan du IVème plan quinquennal (1986-1990), Ann. Géo., N560, p.438-454.

Lebailly P., Dogot T., Pham Van Bien \& Tran Tien Khai, 2000 - La filière rizicole du Sud Viêt-nam. Un modèle méthodologique - Les presses agronomiques de Gembloux, Belgique, $142 \mathrm{p}$.

Malleret L., 1962, - L'archéologie du delta du Mékong, tome III (texte), EFEO, Paris,

MELIN P., 1939 - L'endettement agraire en Indochine - Paris 
NGUYEN DinH DÂU, 1995 - Nghiên cuu dia ba triêu nguyên An Giang (Etude des cadastres de An Giang de la dynastie des Nguyên) - maison d'édition de Ho Chi Minh ville, Ho Chi Minh ville, Viêt-nam, $407 \mathrm{p}$.

Nguyen HuU ChIEM, 1994 - Studies on agro-ecological environment and land use in the Mekong delta, Vietnam - PhD. Dissertation, Graduate school of agriculture Kyoto university, $237 \mathrm{p}$.

NguYen VAn Long, 1984 - Khai Quat Nhung "Go Da" o Khu Di Tich Oc Eo (Thoai Son An Giang) "fouilles des vestiges des "monticules de pierre" excavation dans la zone de Oc Eo, Thoai Son, An Giang"- So Van Hoa va Thong Tin An Giang Xuat Ban (service de l'information et de la culture de la province d'An Giang), pp.189-198.

Nguyen Xuan Hien, 1984 - Nghe Trong Lua Co o Oc Eo "la culture du riz à Oc Eo" - So Van Hoa va Thong Tin An Giang Xuat Ban (service de l'information et de la culture de la province d'An Giang), pp.239-245.

Pingali L. P. \& Vo TONG XUAN, 1992 - Vietnam: decollectivisation and rice productivity growth - in Economic Development and Cultural Change, Vol. 4, n²4, july 1992, The University of Chicago Press, Chicago, pp. 697-718.

Robequain C., 1939 - L'évolution économique de l'Indochine et du Viêt-nam - CEPE, publication, $N^{\circ} 13$, Hartman P. Editeur, Paris, 394 p.

SCHULDERS G., 1997 - Rythmes et séquences de la transition économique asiatique. La Chine et le Viêt-nam - in Etats, politiques publiques et développement en Asie de 1'Est, Gemdev, Karthala, Paris, 236 p.

SCHREINER A., 1900 - Les institutions annamites en Basse Cochinchine avant la conquête française - Claude \& cie, 3 vol., Saigon, Vietnam

Vo Tong Xuan, 1975 - Rice cultivation in Mekong Delta. Present situation and potentials for increased production - SouthEast Asian Studies, Vol 13, $\mathrm{N}^{\circ} 1$, June. Kyoto, Japon, pp. 88-109. 


\section{Illustration table}

Figure 1. Location of the Mekong Delta in Vietnam.

Figure 2. Geomorphological units of the Mekong Delta and location of the Omon district.

Figure 3. Summary of the socio-economic environment and agro-ecosystems transformations in the Omon district of the Mekong Delta.

Figure 4.a. Long term evolution of paddy production in South Vietnam $(1880-1995)$.

Figure 4.b. Long term evolution of per capita paddy production and disposable volumes in South Vietnam.

Figure 5. Land use in Omon district in 1850 under the Vietnamese Empire.

Figure 6. Farmers categories in the Omon district during the Vietnamese imperial and the French colonial regimes.

Figure 7. Land use in Omon district in 1930 under the French colonial regime.

Figure 8. Farmers categories in Omon district during the Republic of South Vietnam (1955 $-1975)$.

Figure 9. Land use in Omon district in 1965 under the Republic of South Vietnam prior to the introduction of the HYV rice.

Figure 10. Land use in Omon district in 1975 under the Republic of South Vietnam.

Figure 11. Evolution of farmer's categories in Omon district during the first decade of the Socialist Republic of Vietnam (1975-1985).

Figure 12. Land use in Omon district in 1985 under the Socialist Republic of Vietnam.

Figure 13. Evolution of farmers categories during the Socialist Republic of Vietnam after the implementation of the liberalisation policy (1985-1995).

Figure 14. Land use in Omon district in 1995 under the Socialist Republic of Vietnam. 
Figure 1. Location of the Mekong Delta in Vietnam.

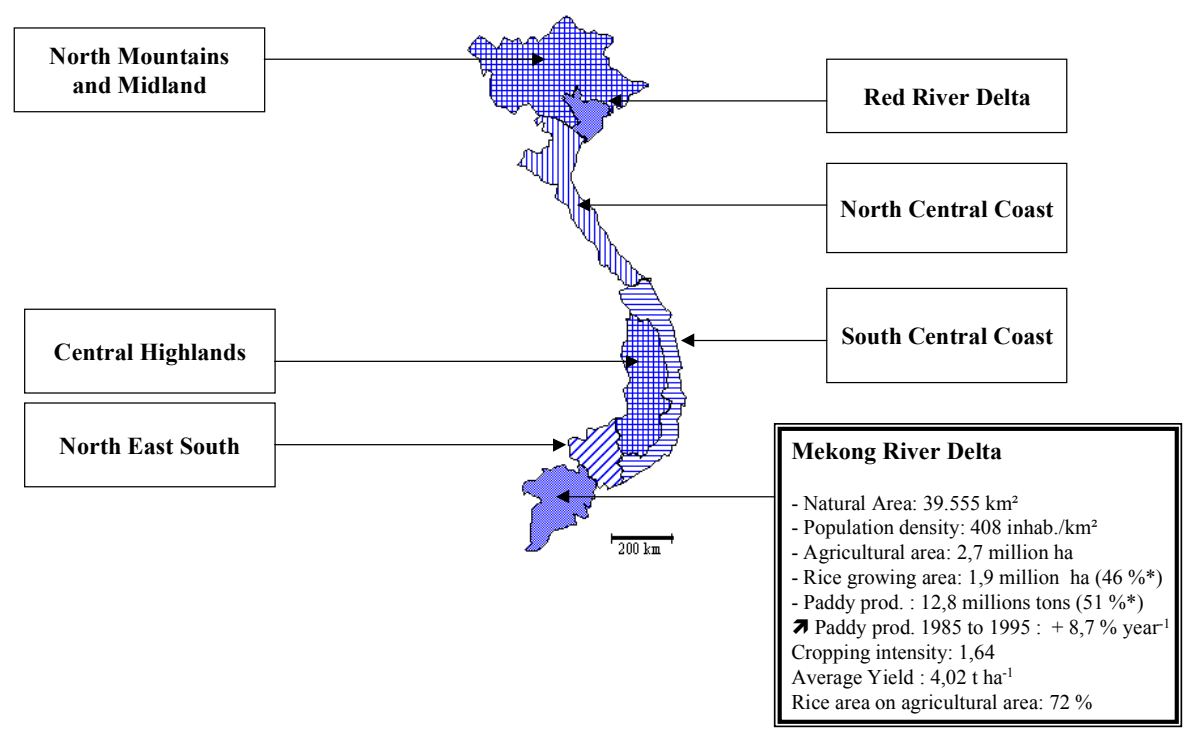

Source: data of 1995 from General Statistical Office, 1996 NB: *: percentage of national figures.

Figure 2. Geomorphological units of the Mekong Delta and location of the Omon district.

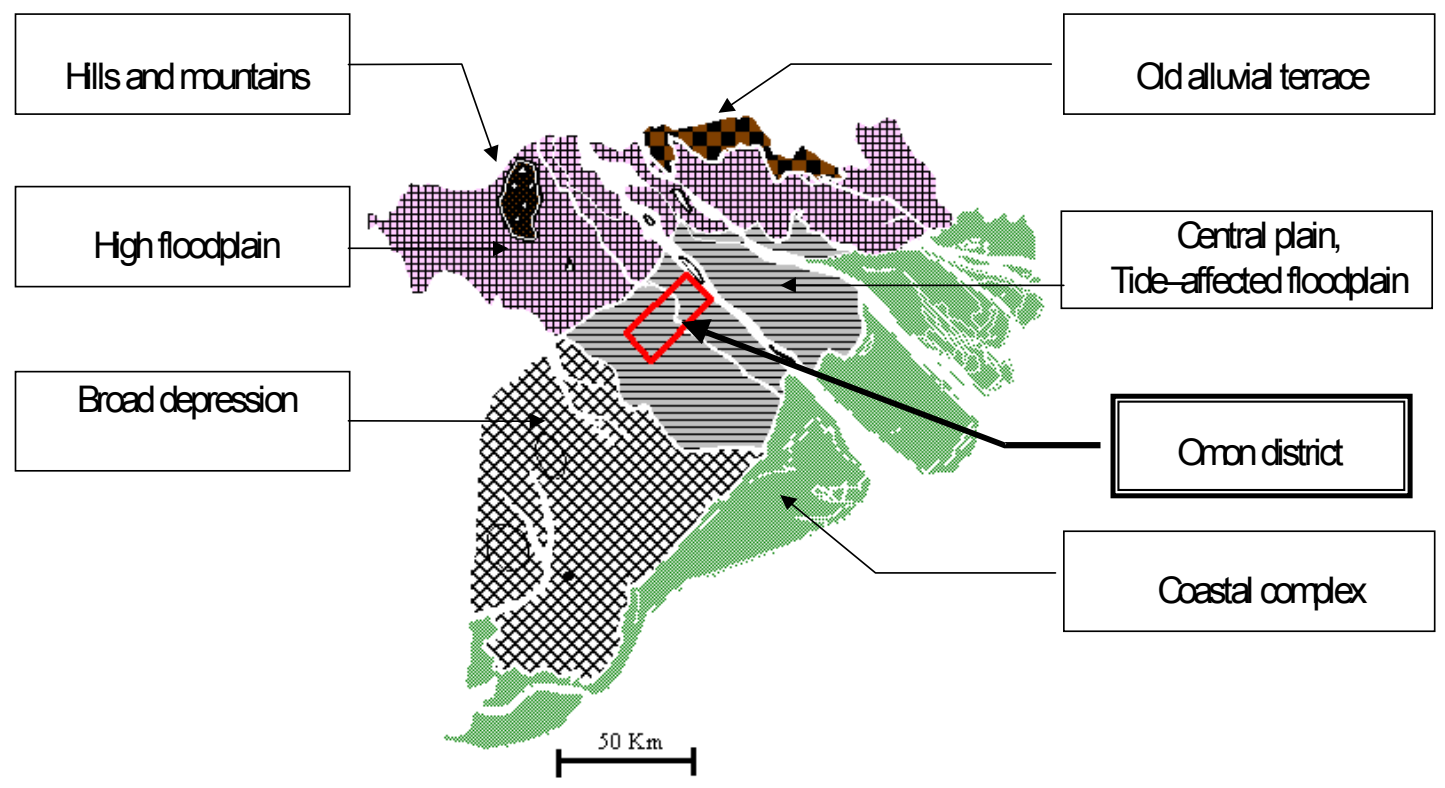

Source : from NEDECO (1992) and Nguyen Huu Chiem (1994) 
Figure 3. Summary of the socio-economic environment and agro-ecosystems transformations in the Omon district of the Mekong Delta.

Transformation of

the agro-ecosystem

Reclamation of levees by first Vietnamese settlers: rainfed rice system / shallow submergence prone ecosystem,

Expansion of rice cultivation on the medium deep waterlogged plain.

Reclamation of deep water ecosystem (upper and lower floodplain),

Domination of doubly transplanted rice, production system with manual tools,

Limited increase of draft animals,

Rice production specialisation.

Deterioration of the hydraulic network,

Dereliction of agricultural land especially in the lower plain.

Re-reclamation of fallow land.

Beginning of rice intensification,

Beginning of non-rice productions (orchards, vegetables).

Introduction of HYV varieties: start of the « Green Revolution».

First adoption and rapid expansion of irrigated HYV rice-based cropping systems on levees and in the upper alluvial plain,

Increase in non rice productions (orchards, vegetables, sugarcane).

Expansion of irrigated HYV rice-based cropping systems on levees and in the upper floodplain.

Irrigated HYV rice-based cropping systems cover all the levees and the upper floodplain Lack of agricultural inputs and motomechanised equipment.

Rice intensification : irrigated HYV rice-based cropping systems on lower floodplain, triple cropping on levees and in the upper floodplain, Diversification of production: development of fruit and sugarcane plantations

Legend : HYV : High Yield Rice Varieties

\section{Evolution of}

the socio-economic environment
1967

1970 Second land reform - «Land To The Tiller»: farmers' access to ownership,

Development of moto-mechanisation: tube pumps, hand tractors, axial flow thresher, etc.

1976 Peace and reunification: Mekong Delta in the Socialist Republic of Vietnam

Rapid demographic growth,

Farmers return to countryside.

1981 Creation of "production groups", state control of marketing, land redistribution, expansion and redigging of canals, development of non-rice production is forbidden.

1990 Liberalisation policy:

Dissolution of "production groups", commercial liberalisation, opening to international trade, land and equipment tenure recognition, development of markets for non rice production, development of off-farm jobs (transports, processing,etc.), Rice exports reach $2-4$ millions tons per year. 
Figure 4.a. Long term evolution of paddy production in South Vietnam (1880 - 1995).

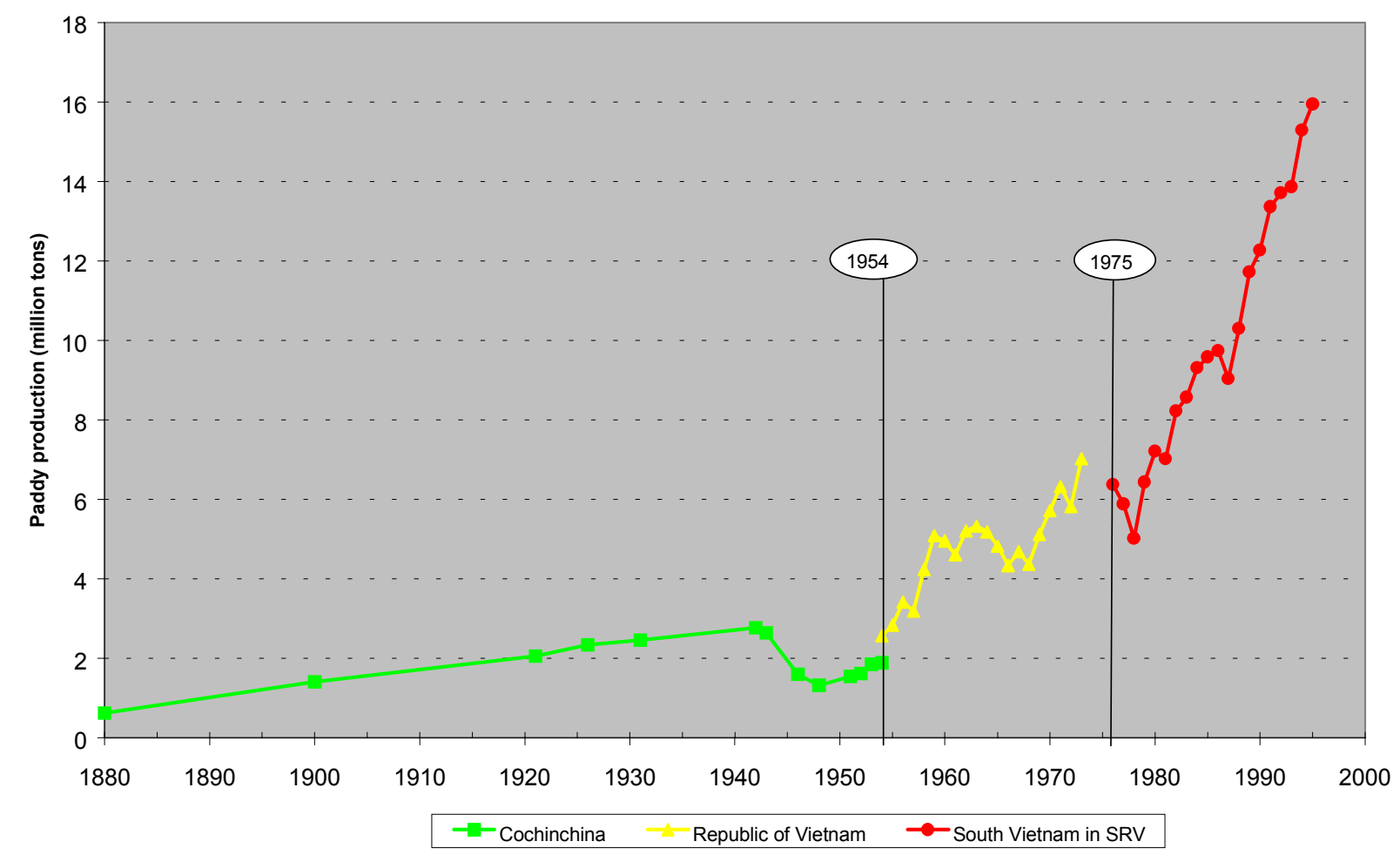

NB: SRV: Socialist Republic of Vietnam

Figure 4.b. Long term evolution of per capita paddy production and disposable volumes in South Vietnam.

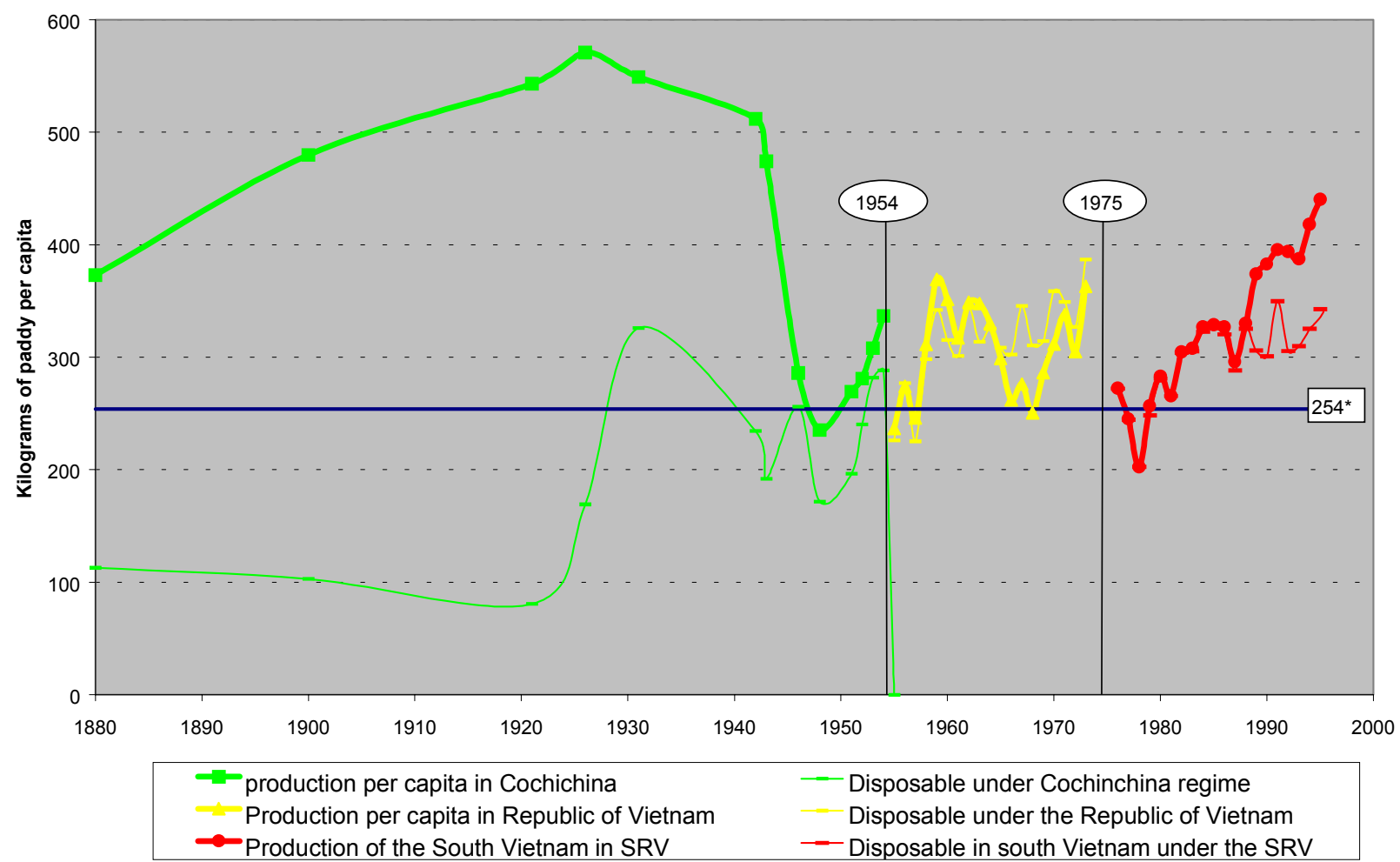

NB: SRV: Socialist Republic of Vietnam

The threshold of $254 \mathrm{~kg}$ per capita corresponds to a relatively suitable level consumption of $165 \mathrm{~kg}$ of white rice per capita per year. 
Figure 5. Land use in Omon district in 1850 under the Vietnamese Empire. 


\section{Figure 5. Land use in Omon district in 1850 under the Vietnamese Empire.}

Main indicators:

Population density (inhabitants $\left./ \mathrm{km}^{2}\right)=20$

Percentage of cultivated area $=10$

Physical productivity (tons of paddy ha $^{-1}$ year $^{-1}$ ) $<1,5$

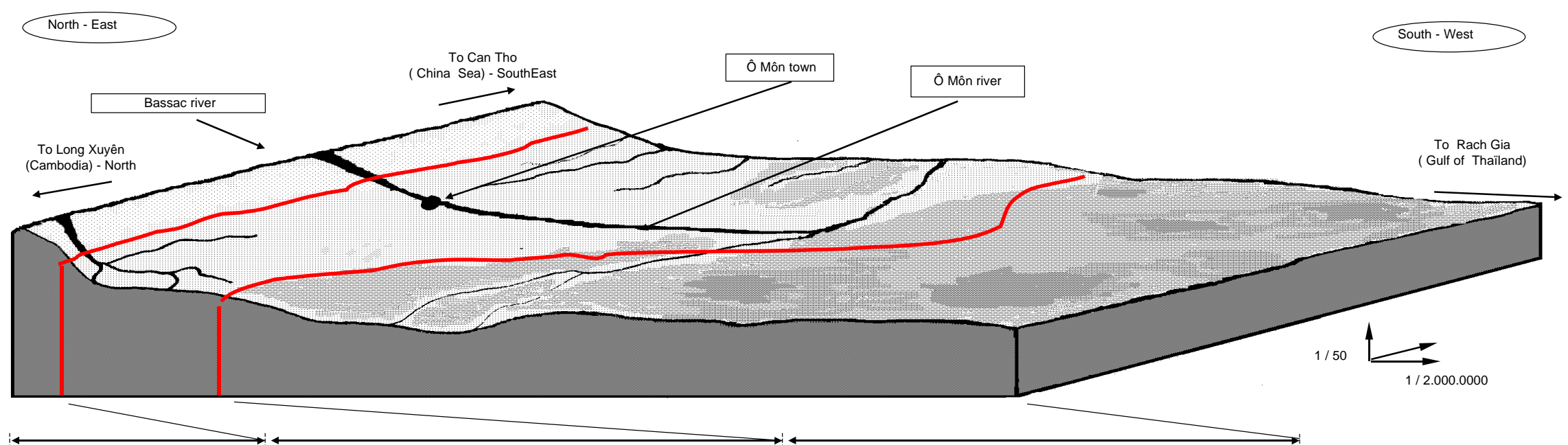

\begin{tabular}{|c|c|c|c|c|c|}
\hline \multirow{2}{*}{$\begin{array}{c}\text { Landform units } \\
\text { Rice Sub-ecosystems }\end{array}$} & \multirow{2}{*}{$\begin{array}{c}\text { Natural levee } \\
\text { Rainfed } \\
\text { shallow submergence prone }\end{array}$} & \multicolumn{2}{|c|}{ Upper Alluvial Plain } & \multicolumn{2}{|c|}{ Lower Alluvial Plain } \\
\hline & & $\begin{array}{c}\text { Rainfed } \\
\text { medium deep waterlogged }\end{array}$ & Deep water & Deep water & Very Deep water \\
\hline Non rice productions & vegetables, tubers and orchards & & & & \\
\hline Type of rice production system & $\begin{array}{l}\text { traditional tran } \\
\text { with or without land preparation } \\
\text { manual or draft animals }\end{array}$ & $\begin{array}{l}\text { ted local rice } \\
\text { without land preparation } \\
\text { manual tools }\end{array}$ & & & \\
\hline Animal husbandry & $\begin{array}{l}\text { swine, poultry } \\
\text { water buffalo and cattle (wet season) }\end{array}$ & \multicolumn{2}{|c|}{$\begin{array}{l}\text { Ducks } \\
\text { water buffalo and cattle (grazing during the dry season) }\end{array}$} & & \\
\hline Other agricultural activities & & \multicolumn{4}{|c|}{$\begin{array}{c}\begin{array}{c}\text { Fisheries all around the year } \\
\text { fisheries during the dry saison } \\
\text { Hunting, gathering, logging, firewood collection,etc... }\end{array} \\
\end{array}$} \\
\hline Off-farm activities & & & & & \\
\hline
\end{tabular}


Figure 7. Land use in Omon district in 1930 during the French colonial regime.

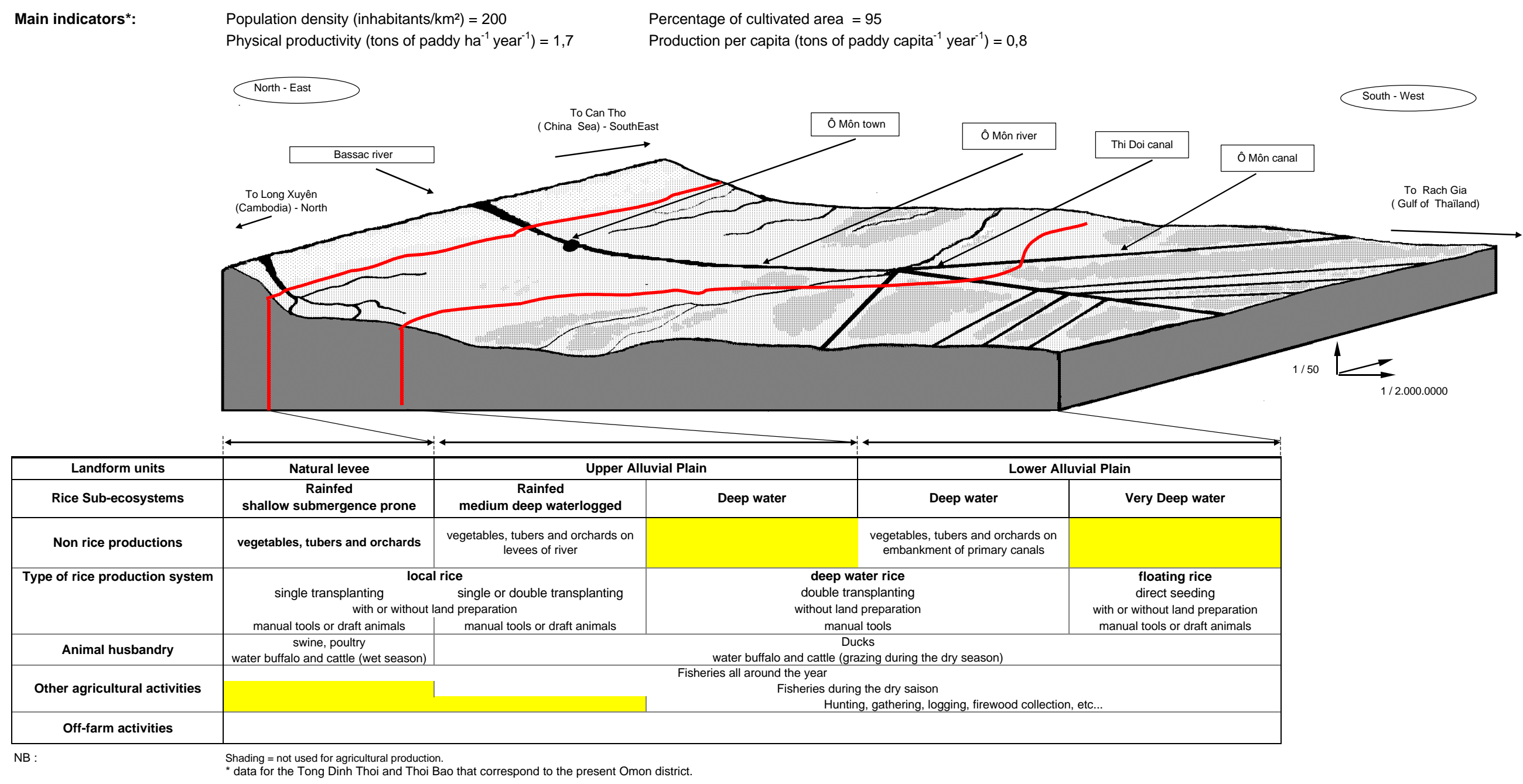




\section{Figure 9. Land use in Omon district in 1965 during the Republic of South Vietnam, prior to the introduction of the rice HYV}
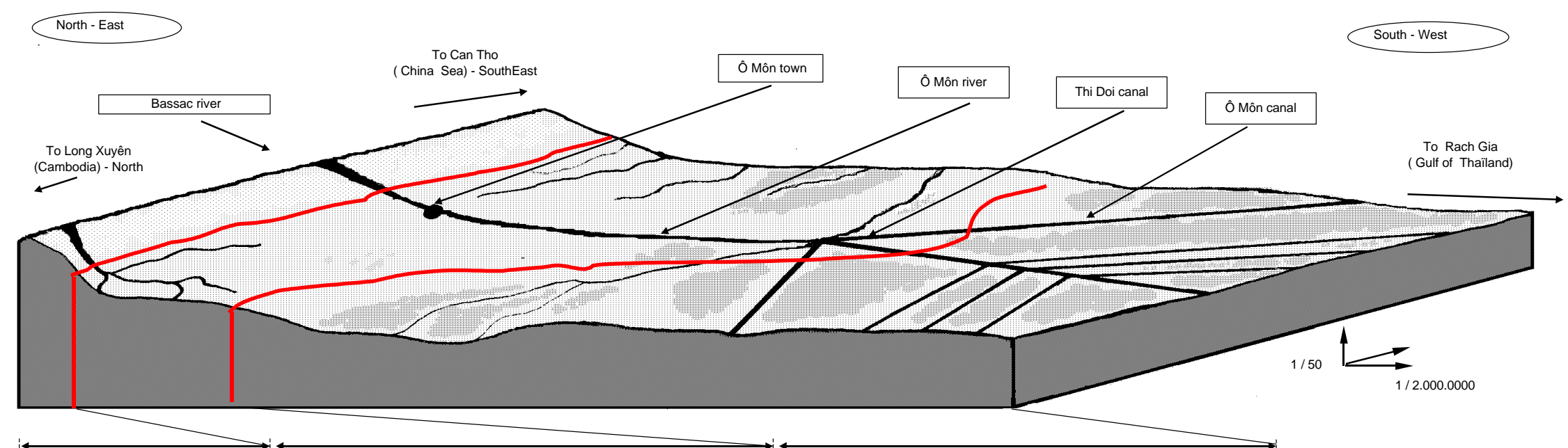

\begin{tabular}{|c|c|c|c|c|c|}
\hline \multirow{2}{*}{$\begin{array}{c}\text { Landform units } \\
\text { Rice Sub-ecosystems }\end{array}$} & \multirow{2}{*}{$\begin{array}{c}\text { Natural levee } \\
\text { Rainfed } \\
\text { shallow submergence prone }\end{array}$} & \multicolumn{2}{|c|}{ Upper Alluvial Plain } & \multicolumn{2}{|c|}{ Lower Alluvial Plain } \\
\hline & & $\begin{array}{c}\text { Rainfed } \\
\text { medium deep waterlogged }\end{array}$ & Deep water & Deep water & Very Deep water \\
\hline Non rice productions & vegetables, tubers and orchards & $\begin{array}{l}\text { vegetables, tubers and orchards on } \\
\text { river levees }\end{array}$ & & $\begin{array}{l}\text { vegetables, tubers and orchards on } \\
\text { embankment of primary canals }\end{array}$ & \\
\hline Type of rice production system & $\begin{array}{l}\text { loca } \\
\text { transplanted or direct seeded } \\
\text { or } 2 \text { local rice year-1 } \\
\text { with land } p \\
\text { draft animals or } r\end{array}$ & $\begin{array}{l}\text { rice } \\
\text { transplanted or direct seeded } \\
\text { eparation } \\
\text { oto-mechanised }\end{array}$ & \multicolumn{2}{|c|}{$\begin{array}{c}\text { deep water rice } \\
\text { single or double transplanted or direct seeded } \\
\text { with or without land preparation } \\
\text { manual tools, draft animals or moto-mechanise }\end{array}$} & $\begin{array}{l}\text { floating rice } \\
\text { direct seeded }\end{array}$ \\
\hline Animal husbandry & $\begin{array}{l}\text { swine, poultry } \\
\text { water buffalo and cattle (wet season) }\end{array}$ & \multicolumn{4}{|c|}{$\begin{array}{c}\text { Ducks } \\
\text { water buffalo and cattle (grazing during the dry season) }\end{array}$} \\
\hline Other agricultural activities & & \multicolumn{4}{|c|}{$\begin{array}{l}\text { Fisheries during the dry saison } \\
\text { Hunting, gathering, logging, firewood collection, etc... }\end{array}$} \\
\hline Off-farm activities & & & & & \\
\hline
\end{tabular}




\section{Figure 10. Land use in Omon district in 1975 during the Republic of Vietnam}

Main indicators:

Population density (inhabitants $\left./ \mathrm{km}^{2}\right)=280-320$

Physical productivity (tons of paddy ha ${ }^{-1}$ year $^{-1}$ ) $=3$

Percentage of cultivated area $=75^{\star *}$

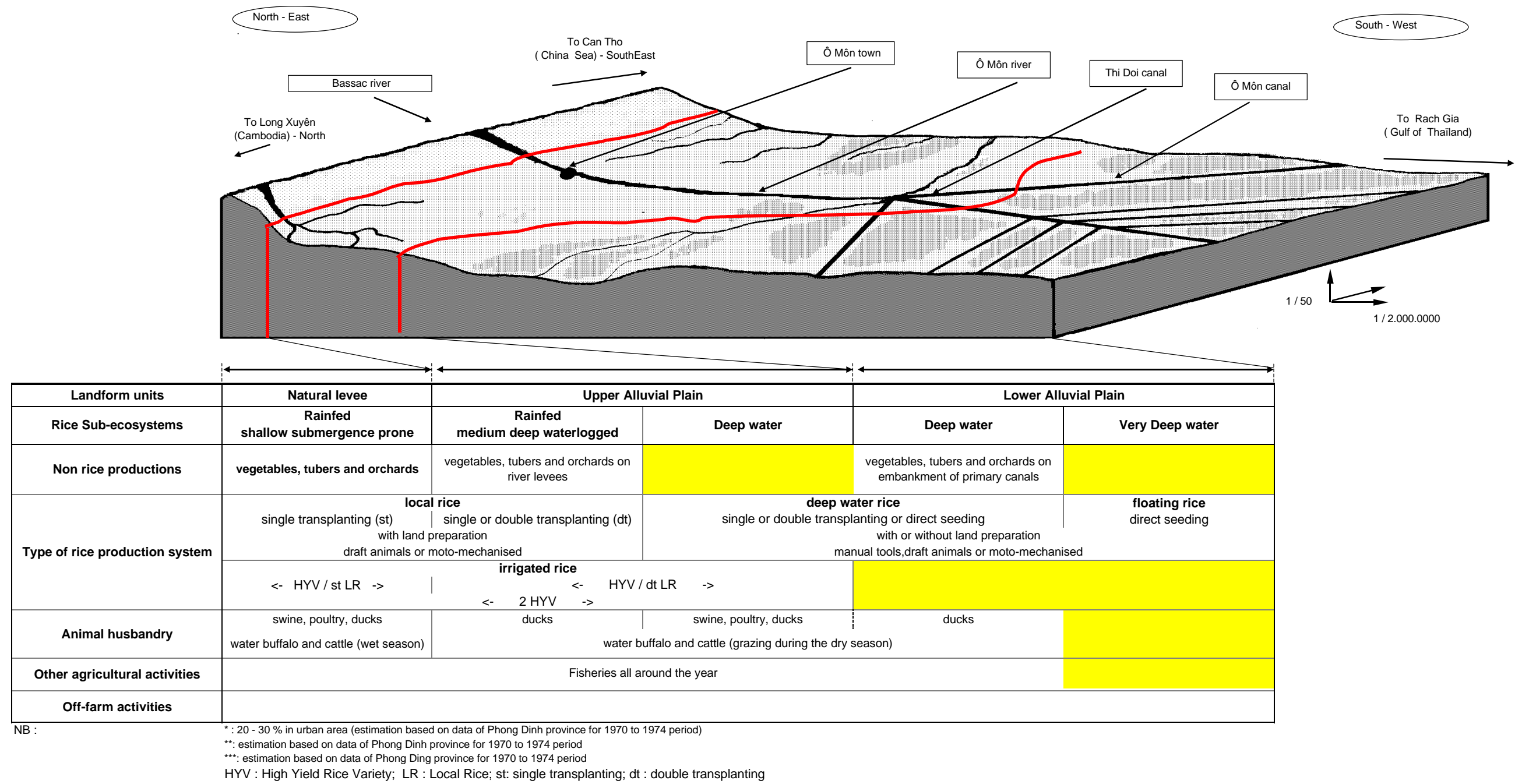




\section{Figure 12. Land use in Omon district in 1985 under the Socialist Republic of Vietnam.}

Main indicators*:

Population density $\left(\right.$ inhabitants $\left./ \mathrm{km}^{2}\right)=440$

Physical productivity (tons of paddy ha $^{-1}$ year $^{-1}$ ) $=3,9$

Percentage of cultivated area $=90$

Production per capita (tons of paddy capita ${ }^{-1}$ year $^{-1}$ ) $=0,6$

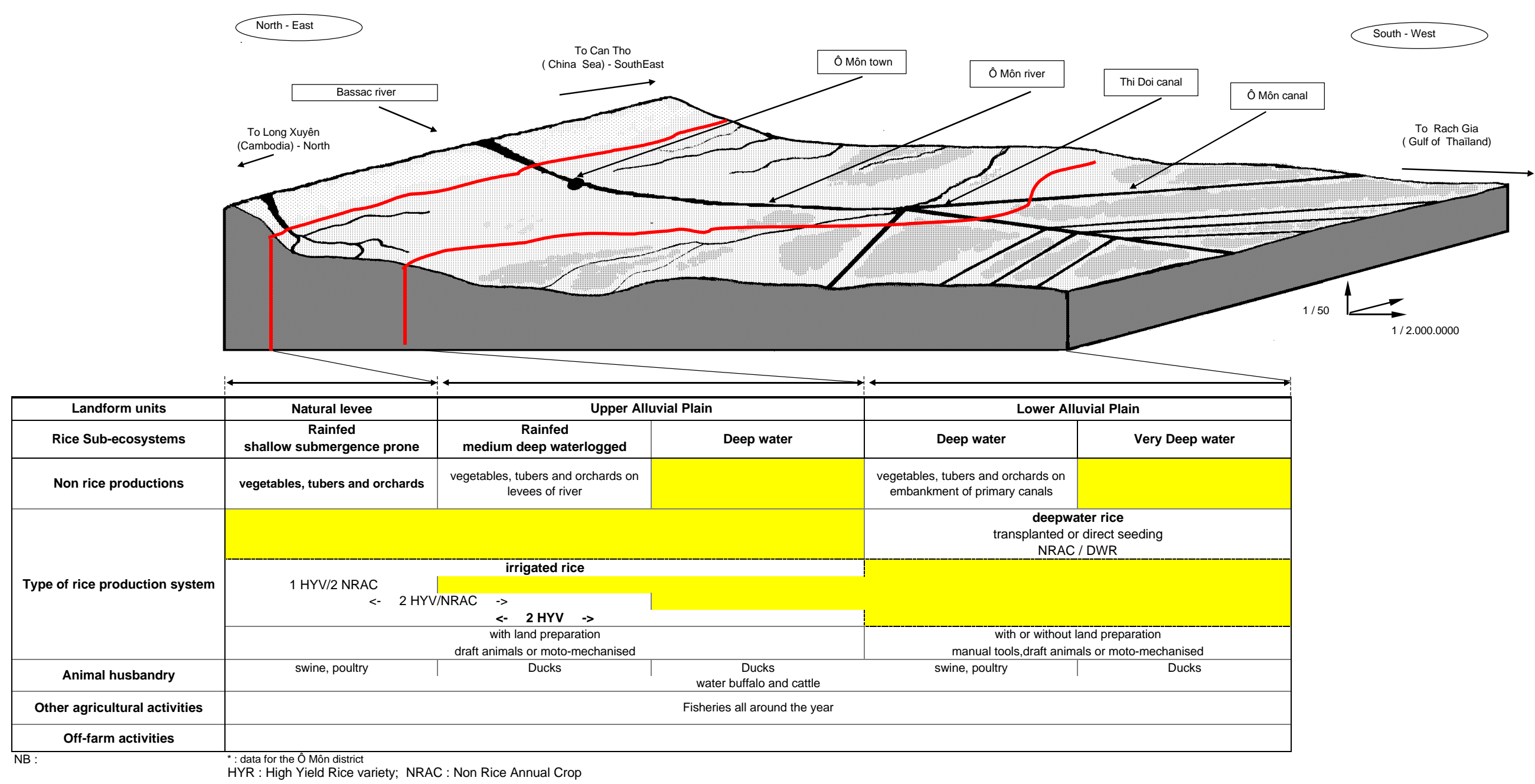


Figure 14. Land use in Omon district in 1995 under the Socialist Republic of Vietnam.

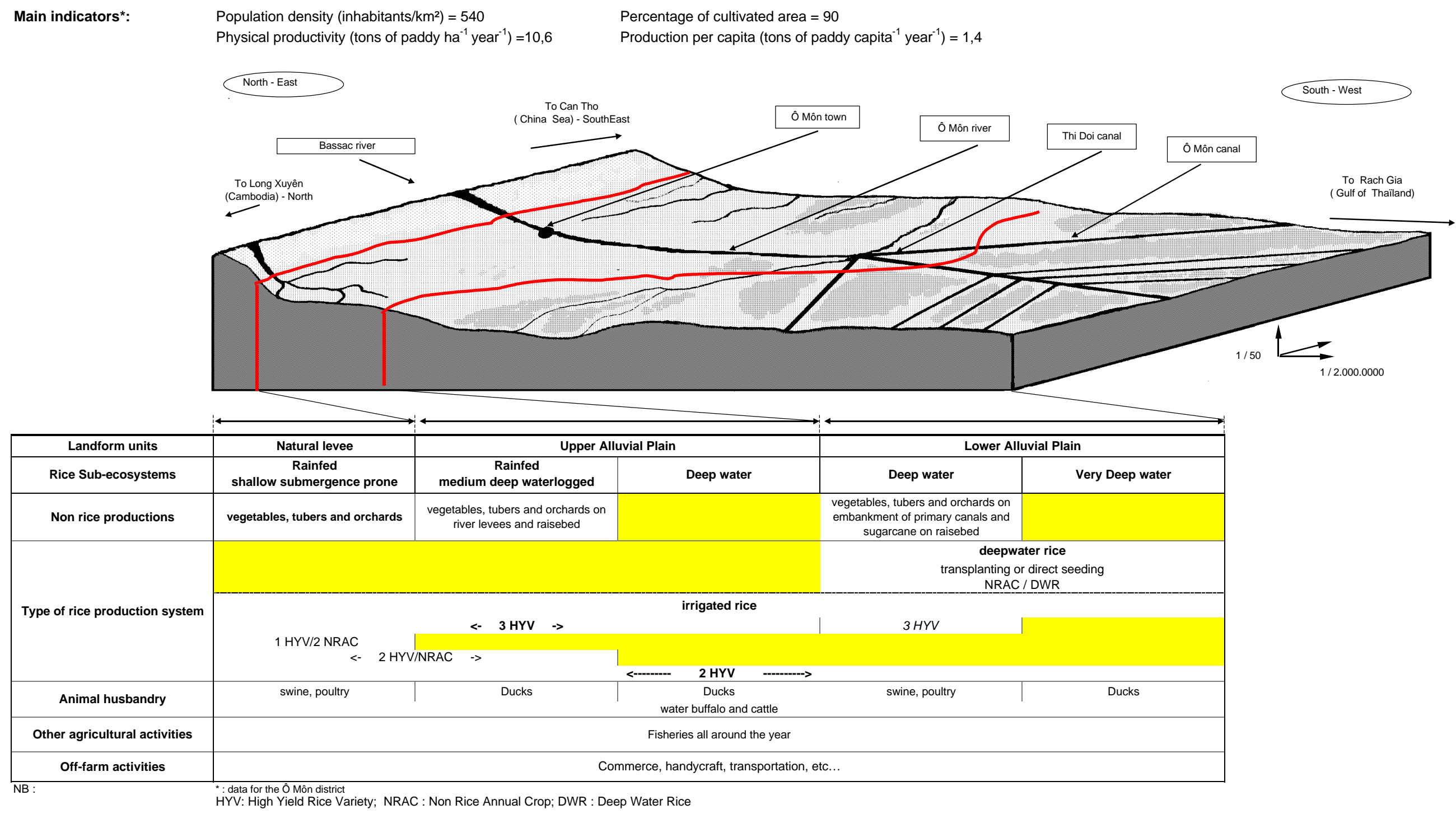

